\title{
IMPLEMENTASI DANA DESA DALAM PELAKSANAAN PEMBANGUNAN DAN PEMBERDAYAAN MASYARAKAT DI DESA BOLLI KECAMATAN PONRE KABUPATEN BONE
}

\author{
The Implementation of Village Funds for Community Development and Empowerment in Bolli Village, \\ Ponre District, Bone Regency
}

\author{
Ali Yusran ${ }^{1}$, Andi Rasyid Pananrangi², Syamsul Bahri \\ ${ }^{1}$ Magister Ilmu Administrasi Negara Program Pascasarjana Universitas Bosowa \\ ${ }^{2}$ Program Studi Ilmu Administrasi Negara Program Pascasarjana Universitas Bosowa \\ Email: aliyusran@gmail.com \\ Diterima: 04 Januari 2020 \\ Dipublikasikan: 05 Juni 2020
}

\begin{abstract}
ABSTRAK
Dana desa merupakan dana yang bersumber dari Anggaran Pendapatan dan Belanja Negara yang di peruntuhkan untuk desa dan bantuan keuangan dari APBN diharapkan akan menjadi sumber pendapatan desa untuk menunjang pembangunan yang ada di desa. Dana desa digunakan sepenuhnya untuk memfasilitasi pembangunan dan pemberdayaan masyarakat desa yang bertujuan untuk meningkatkan kesejahteraan masyarakat desa dan meningkatakan kualitas hidup serta penanggulangan kemiskinan. Tujuan penelitian ini untuk menganalisis implementasi dana desa di Desa Bolli Kecamatan Ponre Kabupaten Bone. Jenis penelitian yang digunakan dalam penelitian ini yaitu penelitian kualitatif dengan menggunakan metode penelitian deskriptif analitis. Penelitian ini menggunakan purposive sampling dalam pengambilan sampel dengan menentukan beberapa informan dengan kriteria yang telah di tentukan terlebih dahulu. Hasil penelitian menunjukkan bahwa penggunaan dana desa dalam pembangunan desa dan pemberdayaan masyarakat di Desa Bolli fokus pada prioritas pembangunan infrastruktur jalan sehingga sarana dan prasarana lain yang dibutuhkan oleh masyarakat tidak terpenuhi.
\end{abstract}

Kata Kunci : Dana Desa, Pembangunan desa, Pemberdayaan Masyarakat, Ponre, Bone

\begin{abstract}
Village funds are funds sourced from the State Budget which is set aside for villages and financial assistance from the State Budget is expected to be a source of village income to support the development in the village. Village funds are used fully to facilitate the development and empowerment of rural communities aimed at improving the welfare of rural communities and improving the quality of life as well as poverty alleviation. The purpose of this study was to describe the implementation of village funds in Bolli Village, Ponre District, Bone Regency. The type of the research used in this study was qualitative research using descriptive analytical research methods. This study used purposive sampling by determining several informants with predetermined criteria. The results show that the implementation of village funds for community development and empowerment in Bolli Village focuses on the priority of road infrastructure development so that other facilities and infrastructure needed by the community are not fulfilled.
\end{abstract}

Keywords: Viillage Funds, Village Development, Community Empowerment, Ponre, Bone

\section{PENDAHULUAN}

Dana Desa adalah dana yang bersumber dari APBN yang diperuntukkan bagi Desa, yang ditransfer melalui anggaran belanja daerah kabupaten atau kota. Dana ini digunakan untuk membiayai penyelenggaraan pemerintahan, pelaksanaan pembangunan, pembinaan kemasyarakatan, dan pemberdayaan masyarakat Desa. Dana Desa di alokasikan dari APBN berdasarkan Pasal 72 Ayat 1 Huruf b Undang-Undang Nomor 6 tahun 2014 tentang Desa. Dalam Peraturan Menteri Dalam Negeri Republik Indonesia No 113 Tahun 2014 Tentang Pengelolaan Keuangan Desa, Dana Desa adalah dana yang bersumber dari Anggaran Pendapatan dan Belanja Negara yang diperuntukkan bagi Desa yang ditransfer melalui Anggaran Pendapatan dan Belanja Daerah Kabupaten atau Kota dan digunakan untuk membiayai penyelenggaraan pemerintahan. Pelaksanaan pembangunan, pembinaan kemasyarakatan, dan pemberdayaan masyarakat. Adanya Dana Desa yang bersumber dari APBN, hal ini menunjukkan rekognisi Negara kepada Desa.

Filosofi dari Dana Desa ialah meningkatkan kesejahteraan dan pemerataan pembangunan Desa melalui peningkatan pelayanan publik di Desa, memajukan perekonomian Desa, mengatasi kesenjangan pembangunan antar Desa serta memperkuat masyarakat Desa sebagai subjek dari pembangunan. Dana desa diharapkan akan menjadi sumber pendapatan desa untuk menunjang pembangunan yang ada di desa. Dana desa digunakan sepenuhnya untuk memfasilitasi pembangunan dan pemberdayaan masyarakat desa yang bertujuan untuk meningkatkan kesejahteraan masyarakat desa, peningkatan kualitas hidup serta penanggulangan kemiskinan. penetapan penggunaan dana desa sesuai 
dengan yang telah di prioritaskan oleh Menteri Desa, Pembangunan Daerah Tertinggal dan Transmigrasi.

Besaran dana desa yang diterima setiap desa, dihitung berdasarkan alokasi dasar kabupaten atau kota dibagi jumlah desa yang telah ditetapkan oleh pemerintah, sedangkan Alokasi formula dihitung berdasarkan jumlah penduduk, angka kemiskinan, luas wilayah dan Indeks kesulitan wilayah .Besaran anggaran dana desa yang akan diterima oleh setiap kabupaten atau kota dari APBN melalui APBD akan berbeda dengan kota yang lain, kemudian dana desa yang diterima akan dibagikan ke setiap desa sesuai dengan ketentuan yang ditetapkan oleh pemerintah.

Penggunaan dana desa pada dasarnya merupakan hak pemerintah desa sesuai dengan kewenangan dan prioritas kebutuhan masyarakat desa setempat dengan tetap mengedepankan prinsip keadilan. Dalam rangka mengawal dan memastikan capaian sasaran pembangunan desa maka ditetapkan. Setiap tahunnya pemerintah pusat mengeluarkan anggaran untuk dana desa, pada tahun 2016 sebesar 20,67 triliun,tahun 2016 sebesar 46,98 triliun, tahun 2017 sebesar 60 triliun, tahun 2018 sebesar 60 triliun dan tahun 2019 sebesar 70 triliun. Dana desa tersebut diberikan keseluruh desa di Indonesia dengan formula 77 persen dibagi rata keseluruh desa kemudian sisahnya di alokasikan untuk tambahan secara proporsional kepada desa berdasarkan jumlah penduduk, tingkat kemiskinan,tingkat kesulitan geografis dan luas wilayah. Pada tahun 2019 desa Bolli mendapat kucuran dana desa dari pemerintah pusat sebesar. Rp. 1.245.581.000. Berdasarkan Peraturan Pemerintah Republik Indonesia Nomor 22 Tahun 2015 Tentang Perubahan Atas Peraturan Pemerintah Nomor 60 Tahun 2014 Tentang Dana Desa Yang Bersumber Dari Anggaran Pendapatn Dan Belanja Negara Pasal 20 bahwa penggunaan Dana Desa mengacu pada Rencana Pembangunan Jangka Menengah desa dan Rencana Kerja Pemerintah Desa.

Pembangunan Desa di tujukan untuk segenap masyarakat, dengan demikian pelaksanaannya menjadi tanggung jawab pemerintah dan masyarakat Desa. Pembangunan Desa bukanlah terfokus dalam suatu bidang saja, akan tetapi harus seimbang, serasi dan mencakup segala bidang. Jelasnya di katakan bahwa keseluruhan kegiatan pembangunan yang mengembangkan swadaya gotong royong. Pembangunan Desa adalah suatu pembangunan yang di arahkan untuk meningkatkan taraf hidup dan kesejahteraan masyarakat Desa.

Berkenaan dengan pembangunan Desa, Sudirwo, (1985) menyatakan merupakan proses perubahan yang terus menerus dan berkesinambungan yang diselenggarakan oleh masyarakat beserta pemerintah untuk meningkatkan kesejahteraan lahir dan batin, mateeri dan spiritual berdasarkan pancasila yang berlangsung di Desa. Dengan demikian, maka pembangunan Desa perlu terus diupayakan karena secara keseluruhan Desa merupakan landasan bagi ketahanan nasional seluruh rakyat Indonesia. Selain itu, untuk mencapai tujuan dari pembangunan Desa itu, pelaksanaan pembangunan di berbagai aspek kehidupan baik aspek ideologi, politik, ekonomi, sosial, budaya dan agama maupun dalam aspek pertahanan dan keamanan. Melalui pembangunan Desa diupayakan agar masyarakat memiliki keuletan dan ketangguhan yang mengandung kemampuan mengatasi berbagai masalah dalam kehidupan.

Pembangunan Desa itu harus meliputi berbagai aspek kehidupan dan penghidupan artinya harus melibatkan semua komponen yaitu dari pihak masyarakat dan pemerintah, dan harus langsung secara terus menerus demi tercapainya kebutuhan pada masa sekarang dan masa yang akan datang. Pemberdayaan masyarakat secara konseptual adalah upaya untuk meningkatkan harkat dan martabat lapisan masyarakat yang dalam kondisi sekarang tidak mampu untuk melepaskan diri dari perangkap kemiskinan dan keterbelakangan. Dengan kata lain memberdayakan adalah memampukan dan memandirikan masyarakat. Prijono dan Pranarka(1996), dalam konsep pemberdayaan, manusia adalah subyek dari dirinya sendiri. Proses pemberdayaan yang menekankan pada proses memberikan kemampuan kepada masyarakat agar menjadi berdaya, mendorong atau memotivasi individu agar mempunyai kemampuan atau keberdayaan untuk menentukan pilihan hidupnya. Lebih lanjut dikatakan bahwa pemberdayaan harus ditujukan pada kelompok atau lapisan masyarakat yang tertinggal.

Sumodiningrat (1999) menyatakan bahwa pemberdayaan masyarakat merupakan upaya untuk memandirikan masyarakat lewat perwujudan potensi kemampuan yang mereka miliki. Adapun pemberdayaan masyarakat senantiasa menyangkut dua kelompok yang saling terkait, yaitu masyarakat sebagai pihak yang diberdayakan dan pihak yang menaruh kepedulian sebagai pihak yang memberdayakan. Moeljarto (1998) menekankan bahwa terkait erat dengan pemberdayaan ekonomi rakyat. Dalam proses pemberdayaan masyarakat diarahkan pada pengembangan sumberdaya manusia, penciptaan peluang usaha yang sesuai dengan keinginan masyarakat. Masyarakat menentukan jenis usaha, kondisi wilayah yang pada gilirannya dapat menciptakan lembaga dan system pelayanan dari, oleh dan untuk masyarakat setempat. Upaya pemberdayaan masyarakat ini kemudian pada pemberdayaan ekonomi rakyat. Keberdayaan dalam konteks masyarakat adalah kemampuan individu yang bersenyawa dalam masyarakat dan membangun keberdayaan masyarakat yang bersangkutan. Suatu masyarakat yang sebagian besar anggotanya sehat fisik dan mental, terdidik dan kuat, tentunya memiliki keberdayaan yang tinggi. Keberdayaan masyarakat merupakan unsur dasar yang memungkinkan suatu masyarakat bertahan, dan dalam pengertian yang dinamis mengembangkan diri dan mencapai kemajuan.

Penelitian ini bertujuan untuk menganalisis implementasi dana desa dalam pelaksanaan pembangunan dan pemberdayaan masyarakat di desa Bolli Kecamatan Ponre Kabupaten Bone sehingga menjadi sumber pendapatan desa dalam menunjang pembangunan serta 
memfasilitasi pembangunan dan pemberdayaan masyarakat desa.

\section{METODE}

\section{Jenis Penelitian}

Jenis penelitian ini dapat digolongkan kedalam penelitian kualitatif, metode penelitian yang di lakukan adalah penelitian deskriptif analitis, metode ini digunakan untuk meneliti kejadian-kejadian yang berhubungan dengan kondisi pada saat ini. Penelitian ini dipilih untuk menyajikan data secara sistematis, faktual, dan akurat terkait fakta-fakta yang ada di lapangan. Dengan menggunakan desain penelitian deskriftif dengan pendekatan kualitatif bertujuan untuk menggali mengenai implementasi dana desa

\section{Teknik Pengumpulan Data dan Infroman}

Penelitan ini penulis menggunakan teknik purposive sampling. dalam hal ini dengan menentukan beberapa informan dengan kriteria yang telah di tentukan terlebih dahulu dan dianggap mengetahuai serta mampu memberikan keterangan tentang masalah yang diteliti. Untuk mendapatkan data empiris maka ditetapkan beberapa pihak yang menjadi informan yaitu (1) Kepala desa, jumlah 1 orang; (2) Sekretaris desa dan bendahara desa, jumlah 2 orang; (3) Kepala dusun, berjumlah 7 orang; dan 94) Ketua BPD, jumlah 1 orang.

Jumlah informan pada penelitian ini adalah 11 Orang. Penentuan informan tersebut didasari pertimbangan bahwa mereka memiliki pengetahuan yang cukup memadai dengan keterlibtan mereka secara lansung dalam kegiatan.

Untuk memperoleh data lapangan, khususnya data primer dan sekuder dalam penelitian ini dilakukan dengan:

1. Data sekunder diperoleh melalui penelusuran studi pustaka, pedoman peraturan perundang-undangan, dokumentasi dan hasil penelitian terdahulu maupun tulisan-tulisan lainnya yang relevan mendukung data yang berkaitan dengan fokus penelitian. Penelitian ini fokus implementasi implementasi Dana Desa di Desa Bolli Kecamatan Ponre Kabupaten Bone. Untuk mendukung data yang diteliti maka dibutuhkan teori, peraturan perundang-undangan dan dokumentasi.

2. Data primer diperoleh melalui teknik wawancara terstruktur, wawancara terbuka dan teknik observasi lapangan. Tujuan wawancara terstruktur, wawancara terbuka dan observasi dilakukan yaitu untuk memperoleh data yang berkaitan dengan implementasi Dana Desa seperti pemenuhan kebutuhan dasar, pembangunan sarana dan prasarana, pengembangan potensi ekonomi lokal, pelestarian sumber daya alam dan lingkingan secara berkelanjutan, peningkatan kapasitas warga, mendukung kegiatan bumdes.

Teknik pengumpulan data berkenaan dengan ketepatan cara-cara yang digunakan untuk mengumpulkan data. Teknik pengumpulan data yang digunakan dalam penelitian ini yaitu:

1. Interview (wawancara)

Wawancara adalah suatu teknik pengumpulan data untuk mendapatkan informasi yang digali dari sumber data langsung melalui percakapan atau tanya jawab. Metode wawancara yang digunaka dalam penelitian ini wawancara terstruktur dengan menggunakan pedoman wawancara dimana telah ditetapkan terlebih dahulu masalah yang dan pertanyaan yang akan diajukan kepada informan yang diwawancarai.

2. Observasi (pengamatan)

Observasi adalah pengamatan terhadap suatu objek yang diteliti baik secara langsung maupun tidak langsung untuk memperoleh data yang harus dikumpulkan dalam penelitian. Secara langsung dengan terlibat ke lapangan dengan melibatkan seluruh pancaindera. Sedangkan tidak langsung dengan dibantu mediavisual atau audiovisual.

3. Library study (studi kepustakaan)

Studi kepustakaan yaitu untuk mendapatkan bahan berupa pengetahuan teoritis dengan membaca literatur yang berkaitan dengan masalah yang akan dibahas untuk di jadikan dasar dan pedoman dalam penelitian ini. Untuk mendukung data yang ada dilapangan maka dilakukan studi kepustakaan agar data yang dilapangan sesuai dengan teori atau aturan yang ada.

Analisis Data

Analisis data dalam penelitian ini dilakukan menggunakan deskriftif analisis yaitu mengunpulkan dan merekap data yang bukan dicatat dalam bentuk aangka namun penjelasan yang yang lebih rinci secara mendalam. Informasi yang dikumpulkan diidentifikasi menjadi konsep, selanjutnya diolah menjadi proposisproposisi. Kemudian dikembangkan dari perbandingan data empiris dengan hasil-hasil penelitian atau teori lain yang relevan.

Berdasarkan penjabaran diatas penelitian ini menggunakan Model Miles and Huberman sebagai teknik analisis data kualitatif, dimana analisis ini dilakukan pada saat pengumpulan data berlansung, dan setelah selesai pengumpulan data dalam periode tertentu. Miles and Huberman dalam Sugiyono (2014) mengatakan bahwa aktivitas dalam analisis data kualitatif dilakukan secara interaktif dan berlansung secara terus menerus hingga tuntas sampai datanya sudah jenuh. Aktivitas dalam analisis data yaitu data reduction, data display dan clonclusion drawing verivikacation.

\section{HASIL DAN PEMBAHASAN}

Kebijakan publik pada dasarnya adalah suatu keputusan yang di maksudkan untuk mengatasi kesalahan tertentu melakukan kegiatan tertentu, atau untuk mencapai tujuan tertentu yang dilakukan oleh instansi yang mempunyai wewenang dalam rangka 
penyelenggaraan tugas pemerintahan negara dan pembangunan berlansung dalam suatu kebijakan tertentu. Kebijakan publik dalam arti luas yaitu kebijakan dalam bentuk peraturan-peraturan pemerintah yang tertulis dalam bentuk peraturan perundang-undangan, dan peraturan-peraturan yang tidak tertulis namun disepakati, yaitu yang disebut dengan konvensi-konvensi. Contoh dari kebijakan publik ini yaitu undang-undang, peraturan pemerintah, peraturan/keputusan presiden, peraturan menteri, peraturan daerah, peraturan/keputusan gubernur dan keputusan peraturan/keputusan bupati. Kebijakan publik biasanya tidak bersifat spesifik dan sempit, tetapi luas dan berada strata strategi. Oleh sebab itu kebijakan publik berfungsi sebagai pedoman umum untuk kebijakan dan keputusan keputusan-keputusan khusus di bawahnya.

Implementasi merupakan langkah yang sangat penting dalam proses kebijakan. Banyak kebijakan yang baik yang mampu dibuat oleh pemerintah, tetapi kemudian ternyata tidak mempunyai pengaruh apa-apa dalam kehidupan negara tersebut karena tidak dilaksanakan. Menurut Deddy Mulyadi (2018) implementasi merupakan tindakan yang dilakukan setelah kebijakan publik di tetapkan, untuk mencapai tujuan ataupun sasaran yang ingin dicapai. Proses implementasi kebijakan publik berbeda dengan proses pembuatan kebijakan publik. Jika pembuatan kebijakan menggunakan proses logika bottom up yaitu proses yang diawali dengangan penyampaian aspirasi, permintaan atau dukungan dari masyarakat. Sedangkan proses implementasi kebijakan publik menggunakan logika top down yaitu penurunan alternatif kebijakan yang abstrak menjadi suatu tindakan yang konkret untuk diterpakan dalam kehidupan masyarakat. Dalam pelayanan public membutuhkan akuntanbilitas agar pelayanan semakin naik (Prabowo et al., (2019). Dalam pelayanan public ini membutuhkan proses implemntasi yang baik pula.

Ripley dan Franklin (1982) menyatakan impelementasi adalah apa yang terjadi setelah undangundang ditetapkan yang memberikan otoritas program, kebijakan, keuntungan (benefit), atau suatu jenis keluaran yang nyata (tangilbe output). Istilah impelementasi menunjuk pada sejumlah kegiatan yang mengikuti pernyataan maksud tentang tujuan-tujuan program dan hasil-hasil yang diinginkan oleh para pejabat pemerintah. Implementasi mencakup tindakan-tindakan (tanpa tindakan-tindakan) oleh berbagai aktor, khususnya para birokrat, yang dimaksudkan untuk membuat program berjalan. Menurut pendapat Gordon dalam pasolong (2008) yaitu: "Implementasi berkenaan dengan berbagai kegiatan yang diarahkan pada realisasi program. Dalam hal ini administrator mengatur cara untuk mengorganisir, menginterpretasikan dan menetapkan kebijakan yang telah diseleksi”.
Observasi di lapangan menunjukkan bahwa desa Bolli dinilai belum maksimal dalam mengimplementasikan dana desa dikarenakan terlalu fokus dalam pembangunan infrastruktur jalan sedangkan masih banyak kebutuhan masyarakat yang sangat mendesak, pemerintah desa Bolli mengabaikan kebutuhan masyarakat yang dinilai sangat urgen dalam kebutuhan sehari-hari, di antaranya kebutuhan air bersih disebagian dusun masih belum ada sumber air bersih. Dalam pemberdayaan masyarakat di desa Bolli tidak terlalu dapat perhatian dari pemerintah desa, beberapa alasan yang mendasari hal tersebut yaitu tidak maksimal dalam melakukan pelatihan dan kurangnya partisipasi masyarakat disegala bidang sehingga budaya gotong royong terabaikan.

Tahun 2019 desa Bolli mendapat kucuran dana desa dari pemerintah pusat sebesar. Rp. 1.245.581.000. Dalam APBDes Desa Bolli Kecamatan Ponre Kabupaten Bone tahun anggaran 2019, pendapatan dari dana desa $=$ Rp.1.245.581.000, BHPR = Rp.20.087.700 dan ADD = Rp.341.806.700 total pendapatan sebesar Rp.1.607.473.400. pembelanjaan dalam bidang penyelenggaraan pemerintah desa $=\mathrm{Rp} .341 .806 .700$, bidang pelaksanaan pembangunan $=$ Rp.1.225.315.000, bidang pembinaan masyarakat $=$ Rp.20.085.700 dan bidang pemberdayaan masyarakat $=\mathrm{Rp} .20 .266 .000$. total pembelanjaan sebesar Rp.1.607.473.400. penggunaan anggaran tersebut terbagi dalam tiga tahap dalam setahun.

Berkaitan dengan hal tersebut diatas bahwa Desa Bolli merupakan Desa agraris, dan produk unggulan disektor pertanian dan Peternakan, di Desa Bolli Untuk subsektor ini menghasilkan 57,5 miliar pada tahun 2019. Dengan perhitungan PDRB atas harga berlaku di Desa Bolli Kecamatan Ponre selama 1 tahun ini meningkat $10 \%$ (persen) dari tahun 2014 yang sebesar 5.7 Miliar Rupiah serta PDRB atas harga konstan Rp. $3.000 / \mathrm{Kg}$ untuk harga gabah dan harga rata-rata untuk harga sapi 7 juta/ekor pada tahun 2019 mengalami peningkatan 575 juta rupiah atau menjadi 57,5 miliar rupiah dari tahun sebelumnya. Kenaikan ini menandakan terjadinya kenaikan produksi barang dan jasa di Desa Bolli Kecamatan Ponre.

\section{Pemenuhan Kebutuhan Dasar}

Pemenuhan kebutuhan dasar merupakan hak yang wajib dipenuhi oleh pemerintah desa kepada masyarakat guna meberikan pelayanan yang baik, dalam pemenuhan kebutuhan dasar terbagi menjadi beberapa aspek yaitu sosial, ekonomi, pendidikan dan kesehatan. Implementasi Dana Desa pemerintah Desa Bolli memperhatikan semua aspek agar semua masyarakat dapat menikmati pelayanan yang baik dengan adanya Dana Desa. Dari aspek sosial akan memberikan pelayanan yang sesuai dengan prosedur pelayanan yang ada, Pemenuhan kebutuhan masyarakat dari aspek ekonomi di Desa Bolli masih mengedepankan pembangunan inrfrastruktur, bantuan dana, bantuan pertanian dan pelatihan. Penghasilan masyarakat di Desa Bolli paling banyak terdapat dari hasil pertanian dan 
peternakan seperti padi, cengkeh, gula merah dan peternakan sapi lokal dan didukung dengan bantuan bibit pertanian lain seperti bantuan pertanian, dari segi pendidikan yaitu dengan mendirikan fasilitas terhadap pendidikan anak usia dini (PAUD), itu merupakan suatu upaya pembinaan yang ditujukan bagi anak usia dini untuk memberikan rangsangan pendidikan terhadap anak usia dini di Desa Bolli dan dari aspek dari aspek kesehatan mengupayakan agar tenaga kesehatan memberi pelayanan yang baik terhadap masyarakat di Desa Bolli.

Penelitian menunjukkan bahwa pemerintah Desa Bolli belum memenuhi semua kebutuhan masyarakat yang di anggap sangat dibutuhkan oleh masyarakat dan pelayanan dari setiap aspek belum terlalu maksimal. Pelayanan publik belum maksimal disebabkan tidak aktifnya beberapa aparat desa sehingga masyarakat yang membutuhkan pelayanan tidak bisa terlayani dengan baik, tidak efektifnya pelatihan yang diberikan oleh pemerintah desa sehingga tidak terlihat hasil yang baik, belum menyediakan PAUD setiap dusun sehingga anak usia dini yang jauh dari PAUD susah menjangkau dan tidak disediakan mobil sosial atau mobil ambulans sehingga masyarakat yang ada pada wilayah yang jauh dari poskesde atau puskesmas susah untuk berobat.

Pemenuhan kebutuhan dasar di Desa Bolli merupakan hal yang sangat di perhatikan oleh pemerintah Desa Bolli. Pemerintah Desa Bolli berusaha untuk memperbaiki segala aspek, dengan memperbaiki aspek tersebut di harapkan Desa Bolli dapat lebih berkembang.

\section{Pembangunan Sarana dan Prasarana}

Implementasi pemenuhan kebutuhan dasar di Desa Bolli merupakan hal yang di prioritaskan oleh pemerintah Desa Bolli, melihat Desa Bolli masih tertinggal dari segi pemenuhan kebutuhan sarana dan prasarana. Dalam wawancara peneliti terhadap informan. AN selaku kepala desa, mengatakan:"Pembangunan sarana dan prasarana merupakan salah satu yang diprioritaskan dalam Desa Bolli terkait dengan perencanaan pembangunan yang telah direncanakan dalam musrenbang. Sebagian pembangunan ada yang telah di selesaikan dan sudah dinikmati oleh masyarakat. Terkait dengan perencanaan program yang belum terlaksana akan dikerjakan di tahap berikutnya melalui anggaran Dana Desa. Program yang kami sudah jalankan yaitu jalan desa dan jembatan merupakan prioritas utama, PAUD, penyediaan air bersih berupa sumur galian dan sumur bor kemudian kami juga sudah menyediakan drainase".

Dalam perencanan pembangunan pemerintah Desa Bolli memprioritas pembangunan infrastruktur jalan desa dan jembatan. Implementasi pembangunan jalan desa dan jembatan telah terlaksana di lima Dusun yaitu Dusun Bolli Dusun Ciro, Dusun Barugae, Dusun Sancereng dan Dusun Maroanging. Pembangunan jalan desa dan jembatan di bangun di lima Dusun tersebut selain Dusun Bolli empat Dusun tersebut belum tersentuh aspal sama sekali maka keempat Dusun tersebut menjadi prioritas dalam pembangunan jalan desa. Kemudian penyediaan sarana prasarana yaitu PAUD telah dibangun di Dusun
Sancereng dan Dusun Maroanging. Untuk penyediaan air bersih pemerintah Desa Bolli telah menyediakan sumur galian dan sumur bor dan untuk mendukung petani dibidang pertanian pemerintah Desa Bolli telah membangun drainase.

Untuk mengetahui secara spesifik terkait pembangunan sarana dan prasarana yang telah dibangun atau disediakan peneliti melakukan wawancarai terhadap AJ selaku sekretsris desa, mengatakan "Jalan desa sudah dibangun melalui anggaran Dana Desa seapanjang 5570 meter, yaitu terdapat di Dusun Ciro,Dusun Barugae, Dusun Sancereng dan Dusun Maroanging, dan jembatan 8 unit terdapat di Dusun bolli 2 unit, di Dusun Ciro 1 unit, Dusun Barugae 1 unit Dusun Sancereng 2 unit dan Dusun Maroanging 2 unit. Penggunaan anggaran Dana Desa dalam pembangunan jalan desa dan jembatan sekitar $85 \%$ dari Rp. 1.245.581.000 anggaran yang diterima Desa Bolli dalam Dana Desa. Kemudian pembuatan PAUD terdapat 2 unit, 1 di Dusun Sancereng dan 1 di Dusun Maroanging, dan sumur 7 unit yang tersebar di setiap Dusun kalau drainase hanya 50 meter di Dusun Sancereng. Dan kami juga sudah membangun jalan tani di Dusun Lawari Dusun Padangloang, Dusun Barugae, Dusun Sancereng dan Dusun Maroanging".

Melihat kondisi geografis di Desa Bolli yang di aliri beberapa sungai dalam beberapa Dusun membuat pemerintah Desa Bolli harus merealisasikan sebagian besar Dana Desa untuk membangun jembatan, karena dengan adanya jembatan merupakan penghubung masyarakat keDusun lainnya dan penghubung kewilayah pertanian. Sebelum adanya jembatan masyarakat kesulitan untuk melewati sungai dengan kendaran, jika musim hujan masyarakat tidak bisa melakukan akses melalui sungai karena sering terjadi banjir. Untuk menyediakan air bersih pemerintah Desa Bolli hanya menyediakan sumur galian dan sumur bor dan itu belum cukup untuk seluruh masyarakat Desa Bolli.

Implementasi Dana Desa di Desa Bolli terkait dengan pembangunan sarana dan prasaran sebagian sudah terlaksana dengan baik dan jika di amati dengan baik pemerintah Desa Bolli fokus pada pembangunan jalan desa dan pembangunan jembatan dan penyediaan saluran air bersih tidak sesuai keinginanan masyarakat karena masyarakat membutuhkan saluran air bersih tetapi pemerintah hanya menyediakan sumur galian dan sumur bor dan masyarakat. Dari sektor pertanian penyediaan embun belum terlaksana dan itu merupakan kebutuhan utama petani di Desa Bolli. Berdasarkan prinsip penggunaan Dana Desa penggunaan Dana Desa harus secara prioritas. Tapi di Desa Bolli masih ada kebutuhan prioritas masyarakat yang belum terpenuhi. Penggunaan Dana Desa pada dasarnya merupakan hak pemerintah desa sesuai dengan kewenangan dan prioritas kebutuhan masyarakat desa setempat dengan tetap mengedepankan prinsip keadilan. Namun demikian, dalam rangka mengawal dan memastikan capaian sasaran pembangunan desa, pemerintah menetapkan prioritas penggunaan Dana Desa setiap tahun. 
Pembangunan sarana dan prasarana adalah hal yang sangat di perhatikan di Desa Bolli. Pemerintah Desa Bolli berusaha memenuhi semua apa yang di butuhkan oleh masyarakat, walaupun belum terpenuhi apa yang di inginkan oleh masyarakat tapi pemerintah Desa Bolli berusaha untuk memenuhi kebutuhan tersebut untuk mendukung aktivitas masyarakat.

\section{Pengembangan Potensi Ekonomi Lokal}

Tujuan pengembangan ekonomi lokal yaitu untuk menciptakan kekayaan, menghasilkan lapangan kerja, meningkatkan pendapatan dan pada akhirnya mengurangi angka kemiskinan dan memperbaiki kualitas hidup masyarakat. Peran pemerintah desa terhadap pengembangan ekonomi lokal yaitu bagaimana agar potensi ekonomi yang ada di didesanya bisa dkelolah dengan baik sehingga bisa memberikan nilai psoitif terhadap masyarakat. Dengan mengandalkan ekonomi lokal, masyarakat dapat lebih kreatif dalam menciptakan suatu produksi yang dapat dipasarkan.

Pengembangan ekonomi lokal yang ada di Desa Bolli ini berupa pelatihan dan menciptakan produk dengan mengandalkan hasil pertanian sendiri, pemamfaatan hasil pertanian yaitu dengan adanya pembuatan kripik pisang di Dusun Lawari dengan mengandalkan hasil pertanin yang merupakan bantuan bibit pisang yang diberikan oleh pemerintah Desa Bolli.

Dengan adanya program tersebut pemerintah Desa Bolli berharap dapat memberikan dampak positif kepada masyarakat yang berpartisipasi. Dampak yang di hasilkan yaitu masyarakat desa yang telah mendapat pelatihan dapat mendirikan usaha konveksi dan warung bakso seghingga dapat memberikan pemasukan tambahan kepada masyarakat. Walaupun tidak melibatkan semua masyarakat tapi sebagian dapat menikmati hasil pelatiahan yang telah diberikan oleh pemerintah desa.

Upaya pemerintah Desa Bolli dalam pengembangan ekonomi lokal yaitu dengan dengan memberikan bantuan modal kepada masyarakat dan memberdayakan masyarakat dengan mengadakan pelatihan kepada masyarakat untuk memberikan pengatahuan terhadap masyarakat dengan anggaran Dana Desa untuk meningkatkan potensi ekonomi di Desa Bolli agar angka kemiskinan dan ekonomi masyarakat dapat meningkat.

\section{Pelestarian Sumber Daya Alam dan Lingkungan secara} Berkelanjutan

Keadaan geografis di Desa Bolli sangat potensial dapat dilihat dari keberagaman sumber daya alam seperti hutan lindung, hamparan lahan perkebunan, destinasi wisata air terjun dan situs pemakaman bersejarah, jika di manfaatkan dapat menjadikan Desa Bolli menjadi desa yang mandiri. Dengan memanfaatkan keberagaman sumber daya alam dan lingkungan yang potensial tersebut dapat memberikan pemasukan yang memadai untuk modal pengembangan pembangunan.

Terdapat dua hal yang di lakukan pemerintah Desa Bolli dalam pelestarian sumber daya alam dan pelestarian lingkugan yaitu upaya untuk menciptakan lokasi wisata pada hutan pinus untuk menarik wisatawan agar bisa memberikan nilai tambah atau pengasilan kepada masyarakat yang mengelolahnya kemudian pelestarian situs makam yang ada di Desa Bolli dengan maksud untuk menghargai makam leluhur.

Pemerintah Desa Bolli sejauh ini hanya memanfaatkan hutan pinus sebagai tempat wisata dan pemeliharaan situs pemakaman bersejarah. Dampak yang diberikan tidak terlihat sama sekali. Berdasarkan observasi peneliti pemanfaatan hutan pinus sebagai tempat wisata tidak lagi dikelola sehingga tidak lagi dkunjungi wisatawan, padahal jika dikelolah dengan baik maka dapat memberikan pemasukan terhadap Desa Bolli dan masyarakat.

Pelestarian sumber daya alam dan lingkungan secara berkelanjutan di Desa Bolli tidak dilaksanakan dengan maksimal melihat potensi sumber daya alam dan lingkuna hidup di Desa Bolli sangat mendukung tapi tidak di kelolah dengan baik oleh pemerintah Desa Bolli.

\section{Peningkatan Kapasitas Warga}

Meningkatkan kapasitas warga adalah salah satu tugas pemerintah dalam menghadapi perkembangan teknologi, melihat persaingan dalam dunia teknologi semakin pesat sehingga pemerintah mengupayakan untuk membangun atau meningkatkan kapsitas warga, oleh karena itu dengan adanya Dana Desa pemerintah telah memberi wewenang kepada pemerintah desa untuk melakukan peningkatan kapasitas warga dengan anggaran Dana Desa. Dorongan pemerintah untuk melakukan peningkatan terhadap warga maka pemerintah desa harus kreatif dalam menciptakan suatu hal yang dapat memberikan pengetahuan yang memadai terhadap warga.

Peningkatan kapasitas warga pemerintah Desa Bolli berupa penyuluhan usaha pertanian. Penyuluhan pertanian di fasilitasi oleh pemerintah desa dan melibatkan dinas pertanian melalui pelatihan untuk memberikan pengetahuan yang baik terkait dengan kegiatan pertanian. Itu dilakukaan agar masyarakat Desa Bolli dapat hasil panen yang lebih baik dan berkualitas dan dapat mengatasi gangguan hama yang selama ini banyak merugikan masyarakat.

Peningkatan kapasitas warga di Desa Bolli merupakan upaya pemerintah desa untuk memandirikan masyarakat lewat perwujudan potensi kemampuan yang mereka miliki. Salah satu usaha pemerintah Desa Bolli dalam meningkatkan kapsitas warga yaitu dengan melakukan penyuluhan pertanian untuk meningkatakan pengetahuan kepada petani agar bisa mengolah lahannya dengan baik dan bisa mengatasi permasalah yang terjadi di lingkungan pertanian.

\section{Mendukung Kegiatan BUMDES}

Badan usaha milik desa (BUMDES) merupakan salah satu kebijakan pemerintah yang dikelolah oleh pemerintah desa atau masyarakat untuk dapat menciptakan usaha dalam wilayah desa demi meningkatkan pendapatan desa. Pemerintah desa di arahkan untuk lebih kreatif dalam menciptakan suatu 
usaha dengan adanya Bumdes. Bumdes dapat di kelolah oleh pemerintah desa atau masyarakat dengan bantuan modal untuk mendirikan suatu usaha.

Kegiatan Bumdes, pemerintah Desa Bolli meberikan bantuan modal kepada masyarakat yang membutuhkan, dalam bantuan modal tersebut pemerintah Desa Bolli telah menyertakan modal kepada dua usaha masyarakat yaitu penyertaan modal untuk mendukung fotografer, bagaimana usaha fotografer dapat berkembang dengan dilibatkan dalam setiap acara masyarakat dan penyertaan modal usaha somel untuk memajukan usaha tersebut agar bisa lebih produktif dalam mengelolah kayu.

Dalam mendukung kegiatan BUMDES di Desa Bolli yaitu dengan penyertaan modal kepada usaha fotografer dan somel dalam mengembangkan usaha tersebut tapi pada kenyataannya kedua usaha tersebut tidak berjalan dengan baik akibat memberikan harga tinggi kepada masyarakat sehinnga masyarakat memilh tempat lain dalam kebutuhan dan media.

Implementasi Dana Desa merupakan tindakan dari rencana pembangunan jangkah menengah RPJMDesa dan RKPD yang dihasilkan melalui musrenbang untuk mencapai desa yang mandiri. Proses implementasi Dana Desa dilakukan dengan tiga tahap dalam satu. Jika implementasi Dana Desa dilakukan dengan melalui pendekatan maka implementasinya akan berjalan dengan sesuai apa yang kita inginkan. Implementasi dari suatu kebijkan pada dasarnya adalah suatu perubahan atau transformasi yang bersifat multiorganisasi, dimana perubahan yang diterapkan melalui implementasi Dana Desa ini mengaitkan berbagai lapisan masyarakat. Oleh karena itu, keberhasilan sangat ditentukan oleh strategi kebijakan tepat yang mampu mengakomodasi berbagai pandangan dan kepentingan yang berbeda dalam masyarakat.

Selain itu keberhasilan suatu implementasi ditentukan dari derajat implementability dari kebijakan tersebut. Implementasi Dana Desa didukung dengan undang-undang dan peraturan lainnya serta melibatkan masyarakat dalam melakukan pengawasan untuk menjamin bahwa implementasi Dana Desa sesuai dengan regulasi atau prosedur yang ada.

Implementasi Dana Desa merupakan aktivitas yang dilakukan untuk mencapai suatu tujuan, implementasi Dana Desa dilakukan untuk memberikan perubahan terhadap suatu desa. Perubahan yang ingin dicapai dalam implementasi Dana Desa yaitu menjadikan desa yang mandiri dan dapat memberikan dampak positif terhadap masyarakat desa dengan adanya pembangunan desa dan pemberdayaan masyarakat.

Implementasi Dana Desa di Desa Bolli merupakan tindak lanjut dari apa yang telah di rencanakan yang sesuai dengan hasil musyawarah. Berdasarkan implementasi Dana Desa di Desa Bolli sesuai apa yang di defenisikan oleh Deddy Mulyadi (2018) bahwa implementasi merupakan tindakan yang dilakukan setelah kebijakan publik di tetapkan, untuk mencapai tujuan ataupun sasaran yang ingin dicapai.
Keberhasilan implementasi menurut Merille S. Grindle dalam Nugroho (2006) dipengaruhi oleh isi kebijakan (content of policy) dan lingkungan kebiakan (content of implementation). Ide dasarnya adalah bahwa setelah kebijakan ditransformasikan, barulah implementasi kebijakan dilakukan. Keberhasilannya ditentukan oleh derajat implementability dari kebijakan tersebut. Isi kebijakan dari implementasi dana desa di Desa Bolli manfaat yang dihasilkan berpengaruh pada empat dusun yang ada di Desa Bolli yaitu Dusun Ciro, Dusun Barugae, Dusun Sancereng Dan Dusun Maroanging karena dalam dusun tersebut banyak pembangunan yang telah direalisasikan. Perubahan sangat signifikan dalam emapat dusun tersebut tapi tidak dengan dusun Bolli, Dusun Lawari dan Dusun Padangloang. Pelaksana dari program yaitu pemerintah Desa Bolli dan semua masyarakat serta stakeholder yang terlibat.

Implementasi kebijakan Dana Desa diperuntukkan untuk melibatkan masyarakat dalam tahap pengerjaannya. Sedangkan lingkungan kebijakan Dana Desa di Desa Bolli maka teridentifikasi ada kepentingan yang menguntukan sebagian pihak dapat dilihat tidak transparansi dalam pengelolaan anggaran, kurangnya informasi yang diberikan kepada masyarakat terkait jumlah anggaran yang digunakan, dalam realisasi program tidak memberikan papan informasi pada program yang direalisasikan. Dengan melibatkan stakeholder yang ada maka salah satu kepentingan yang diinginkan yaitu bagaiman mencari keuntungan dalam setiap realisasi program pembangunan. Karakter dari pemerintah Desa Bolli cenderung tertutup soal penggunaan anggaran Dana Desa sehingga masyarakat merasa tidak puas dengan hasil yang dilihat tanpa melihat berapa anggaran yang digunakan.

\section{KESIMPULAN}

Kesimpulan hasil penelitian ini bahwa implementasi Dana Desa dalam pelaksanaan pembangunan di Desa Bolli difokuskan pada pembangunan infrastruktur. Hasil implementasi Dana Desa di Desa Bolli yang masih kurang efektif karena belum mampu memberikan kesejahteraan terhadap masyarakat sehingga belum bisa menjadikan Desa Bolli sebagai Desa yang mandiri.

\section{DAFTAR PUSTAKA}

Abidin, Zainal Said. 2004. Kebijakan publik. Jakarta: Yayasan Pancur Siwah.

Moeljarto, T. 1998. Politik Pembangunan, Sebuah Analisis, Konsep, Arah Dan Strategi. Yogyakarta: Tiara Wacana.

Mulyadi, Deddy. 2018. Studi Kebijakan Publik Dan Pelayanan Publik. Bandung: Alfabeta

Nugroho, Riant. 2006. Kebijakan Publik Untuk NegaraNegara Berkembang. Jakarta: Elex Media Komputindo 
Pemerintah Indonesia.2014. Prioritas Penggunaan Dana

Desa . Lembaran RI Tahun 2014, No.5. Sekretariat Negara

Pemerintah Indonesia. 2017. Buku Pintar Dana Desa. Lembaran RI Tahun 2017,Sekretariat Negara. Jakarta

Pemerintah Indonesia. 2014. Undang-Undang Nomor 6 Tahun 2014 Tentang Desa. Lembaran RI Tahun 2014, No. 43. Sekretariat Negara. Jakarta.

Pemerintah Indonesia. 2014. Peraturan Menteri Dalam Negeri Republik Indonesia No. 113 Tahun 2014 Tentang Pengelolaan Keuangan Desa. Sekretariat Negara: Jakarta

Pemerintah Indonesia. 2015. Peraturan Pemerintah Republik Indonesia Nomor 22 Tahun 2015 Tentang Perubahan Atas Peraturan Pemerintah Nomor 60 Tahun 2014 Tentang Dana Desa Yang Bersumber APBN. Sekretariat Negara: Jakarta.

Pasolong, Harbani. 2008. Teori Administrasi Publik. Bandung: Alfabeta.

Prabowo, M. T., Pananrangi, A. R., \& Juharni, J. 2019. Kinerja Pelayanan Publik Aparatur Sipil Negara Pada Kantor Kelurahan Rimuku Kecamatan Mamuju Kabupaten Mamuju. Jurnal Paradigma Administrasi Negara, 1(2), 43-53.

Prijono, Onny S Dan Pranarka, A.M.W. 1996. Pemberdayaan Konsep, Kebijakan Dan Implementasi. Jakarta: CSIS.

Rypley, Randall B. And Grace A. Fraklin. 1982. Bureaucracy And Public Implementation. Hommewood: The Dorsey Press.

Sudirwo, D. 1985. Pokok-Pokok Pemerintahan Di Daerah Dan Pemerintahan Desa. Bandung: Aksara

Sugiyono. 2014. Metode Penelitian Pendidikan (Pendekatan Kuantitatif, Kualitatif Dan R\&D). Bandung: Alfabeta

Sumodiningrat, Gunawan. 1999. Pemberdayaan Masyarakat Dan Dan Jaringan Pengaman Sosial. Jakarta: PT. Gramedia Pustaka Utama.

Wibawa, Samodra. 1994. Evaluasi Kebijakan Publik . Jakarta: PT. Raja Grafindo Persada

Winarno, Budi. 2007. Kebijakan Publik Teori dan Proses. Yogyakarta: Media Pressindo 